\title{
Determinan Kejadian Stunting pada Balita di Wilayah Kerja Puskesmas Pekauman Kota Banjarmasin
}

\author{
Norfai ${ }^{1}$, Abdullah ${ }^{2}$ \\ ${ }^{1,2}$ Fakultas Kesehatan Masyarakat Universitas Islam Kalimantan Muhammad Arsyad Al Banjari Banjarmasin \\ Email : norfai92@gmail.com
}

Submitted : 03/10/2020

Accepted: 13/11/2020

Published: $06 / 03 / 2021$

\begin{abstract}
This research is an analytic survey with a Case Control approach with a ratio of 1:1. The sample size was 92 respondents with Purposive Sampling technique. Data collection on stunting events in infants was obtained from secondary data captured at Pekauman Public Health Services, while data on maternal age, maternal education level, maternal height, history of birth weight, exclusive breastfeeding, completeness of basic immunizations, parity, family income and history of pregnancy KEK (chronic energy deficiency) were obtained with the interview method using a questionnaire. Data were analyzed univariate maternal statistics, bivariate statistical Chi Square test statistically there was no relationship between using age, maternal height, history of birth weight, exclusive breastfeeding, completeness of basic immunizations, parity, family income, and history of pregnancy KEK (chronic energy deficiency) with stunting in children under five years. Statistically there is a significant relationship between mother's education level and the incidence of stunting in children under five years in Banjarmasin Pekauman Public Health Services working area. The mother's education level variable is the dominant variable with Odds Ratio of 2.072. Odds Ratio 2.072 means that the low level of education of mothers has the risk of stunting and multivariate statistical tests using the enter method using a computer program with a $95 \%$ confidence level. Based on the results of the study it was found that in infants by 2,072 times greater than the mother's high level of education. It is recommended that comprehensive and intensive education about parenting during the First 1,000 Days of Life is needed, in order to be able to change the mindset of mother who have children under five years about the importance of nutrition in children under five years to health.
\end{abstract}

Keywords : determinants, children under five years stunting events

\begin{abstract}
Abstrak
Penelitian ini merupakan survei analitik dengan pendekatan Case Control dengan rasio perbandingan 1:1. Besar sampel sebanyak 92 responden dengan teknik Purposive Sampling. Pengumpulan data kejadian stunting pada balita didapatkan dari data sekunder yang terekap di Puskesmas Pekauman, sedangkan data umur ibu, tingkat pendidikan ibu, tinggi badan ibu, riwayat berat badan lahir, ASI eksklusif, kelengkapan imunisasi dasar, paritas, pendapatan keluarga dan riwayat KEK kehamilan didapatkan dengan metode wawancara menggunakan kuesioner. Data dianalisis menggunakan statistik univariat, bivariat dan multivariat dengan metode enter menggunakan program komputer dengan tingkat kepercayaan 95\%. Hasil penelitian didapatkan bahwa secara statistik tidak ada hubungan antara umur ibu, tinggi badan ibu, riwayat berat badan lahir, ASI eksklusif, kelengkapan imunisasi dasar, paritas, pendapatan keluarga, dan riwayat KEK kehamilan dengan kejadian stunting pada balita. Secara statistik ada hubungan yang bermakna antara tingkat pendidikan ibu dengan kejadian stunting pada balita di wilayah kerja Puskesmas Pekauman Kota Banjarmasin. Variabel tingkat pendidikan ibu merupakan variabel dominan dengan Odds Ratio 2,072. Odds Ratio 2,072 artinya tingkat pendidikan ibu yang rendah memiliki peluang risiko terjadinya stunting pada balita sebesar 2,072 kali lebih besar dibandingkan tingkat pendidikan ibu yang tinggi. Disarankan perlunya edukasi secara komprehensif dan intensif mengenai pola asuh selama 1.000 Hari Pertama Kehidupan (HPK), agar dapat mengubah pola pikir ibu balita mengenai pentingnya asupan gizi pada balita terhadap kesehatan.
\end{abstract}

Kata kunci : determinan, kejadian stunting balita 


\section{PENDAHULUAN}

Stunting merupakan salah satu target Sustainable Development Goals (SDGs) yang termasuk pada tujuan pembangunan berkelanjutan ke-2 yaitu menghilangkan kelaparan dan segala bentuk malnutrisi pada tahun 2030 serta mencapai ketahanan pangan. Target yang ditetapkan adalah menurunkan angka stunting hingga $40 \%$ pada tahun 2025 (Pusdatin Kemenkes RI, 2018).

Kejadian balita pendek atau biasa disebut dengan stunting merupakan salah satu masalah gizi yang dialami oleh balita di dunia saat ini. Pada tahun 2017 sebesar $22,2 \%$ atau sekitar 150,8 juta balita di dunia mengalami stunting. Namun angka ini sudah mengalami penurunan jika dibandingkan dengan angka stunting pada tahun 2000 yaitu sebesar 32,6\%. Pada tahun 2017, lebih dari setengah balita stunting di dunia berasal dari Asia sebesar $55 \%$ sedangkan lebih dari sepertiganya atau sebesar $39 \%$ tinggal di Afrika. Dari 83,6 juta balita stunting di Asia, proporsi terbanyak berasal dari Asia Selatan sebesar 58,7\% dan proporsi paling sedikit di Asia Tengah sebesar $0,9 \%$. Data prevalensi balita stunting yang dikumpulkan World Health Organization (WHO), Indonesia termasuk ke dalam negara ketiga dengan prevalensi tertinggi di regional Asia Tenggara/South-East Asia Regional (SEAR). Rata-rata prevalensi balita stunting di Indonesia tahun 2005-2017 sebesar 36,4\% (Pusdatin Kemenkes RI, 2018).

Berdasarkan data Riset Kesehatan Dasar (Riskesdas) 2018 prevalensi Stunting secara nasional sebesar $30,8 \%$ yang sebelumnya adalah sebesar $37,2 \%$ pada Riskesdas 2013, sebesar $35,6 \%$ pada Riskesdas 2010 dan sebesar $36,8 \%$ pada Riskesdas 2007, proporsi tersebut mengindikasikan adanya penurunan kejadian stunting pada balita di Indonesia.

Indonesia masih menghadapi permasalahan gizi yang berdampak serius terhadap kualitas Sumber Daya Manusia (SDM). Permasalahan gizi yang dimaksud antara lain kegagalan pertumbuhan pada awal kehidupan seperti berat badan lahir rendah, pendek, kurus dan gemuk yang akan berdampak pada pertumbuhan selanjutnya. Anak yang kekurangan gizi nantinya bisa mengalami hambatan kognitif dan kegagalan pendidikan, sehingga berdampak pada rendahnya produktivitas di masa dewasa. Kurang gizi yang dialami pada awal kehidupan juga berdampak pada peningkatan risiko gangguan metabolik yang berujung pada kejadian penyakit tidak menular pada usia dewasa, seperti Diabetes type II, Stroke, Penyakit Jantung dan lainnya. Salah satu kebijakan nasional dalam upaya perbaikan gizi masyarakat tertuang dalam UndangUndang nomor 36 tahun 2009, bahwa upaya perbaikan gizi ditujukan untuk peningkatan mutu gizi perorangan dan masyarakat (Pusdatin Kemenkes RI, 2018).

Penurunan stunting penting dilakukan sedini mungkin untuk menghindari dampak jangka panjang yang merugikan seperti terhambatnya tumbuh kembang anak. Stunting mempengaruhi perkembangan otak sehingga tingkat kecerdasan anak tidak maksimal. Hal ini berisiko menurunkan produktivitas pada saat dewasa. Stunting juga menjadikan anak lebih rentan terhadap penyakit. Anak stunting berisiko lebih tinggi menderita penyakit kronis di masa dewasanya. Bahkan, stunting dan berbagai bentuk masalah gizi diperkirakan berkontribusi pada hilangnya 2-3\% Produk Domestik Bruto (PDB) setiap tahunnya (Bappenas, 2018).

Berdasarkan RPJMN tahun 20152019 menyebutkan bahwa pembangunan kesehatan dalam periode tahun 2015-2019 difokuskan pada empat program prioritas yaitu penurunan angka kematian ibu dan bayi, penurunan prevalensi balita pendek (stunting), pengendalian penyakit menular dan pengendalian penyakit tidak menular. Upaya peningkatan status gizi masyarakat termasuk penurunan prevalensi balita pendek menjadi salah satu prioritas pembangunan nasional yang tercantum di dalam sasaran 
pokok Rencana Pembangunan jangka Menengah tahun 2015-2019. Target penurunan prevalensi stunting (pendek dan sangat pendek) pada anak baduta (dibawah 2 tahun) adalah menjadi $28 \%$.

Berdasarkan data Dinas Provinsi Kalimantan Selatan kota Banjarmasin tahun 2018 menyatakan bahwa dari 26 puskesmas di wilayah Kota Banjarmasin, Puskesmas Pekauman merupakan puskesmas dengan angka tertinggi balita yang mengalami stunting sebanyak 1.099 yang terdiri dari balita yang berstatus gizi sangat pendek sebanyak 276 dan pendek sebanyak 823 . Data tersebut menunjukkan bahwa data kejadian stunting pada balita masih tinggi, oleh sebab itu berdasarkan data dan urgensi kasus tersebut, maka peneliti perlu melakukan penelitian dengan judul "Determinan Kejadian Stunting pada Balita di Wilayah Kerja Puskesmas Pekauman Kota Banjarmasin Tahun 2019”.

\section{METODE PENELITIAN}

Jenis Penelitian ini merupakan penelitian survey analitik dengan pendekatan Case Control yaitu studi analitik yang menganalisis hubungan kausal yaitu menentukan penyakit (outcome) terlebih dahulu kemudian mengidentifikasi penyebab (faktor risiko). Besar sampel berjumlah 92 responden dengan teknik purposive sampling. Rasio antara kasus dan kontrol adalah 1:1, besar sampel minimal masingmasing 92 pada kelompok kasus dan 92 pada kelompok kontrol. Pengumpulan data primer dilakukan dengan metode wawancara menggunakan kuesioner yang telah disusun mengenai umur ibu, tingkat pendidikan ibu, tinggi badan ibu, riwayat berat badan lahir, ASI eksklusif, kelengkapan imunisasi dasar, paritas, pendapatan keluarga dan riwayat KEK kehamilan. Data dianalisis menggunakan statistik univariat, bivariat uji statistik Chi Square dan uji statistik multivariat dengan metode enter menggunakan program komputer dengan tingkat kepercayaan $95 \%$. Kriteria pengujian menggunakan pendekatan probabilistik yaitu Ho ditolak, apabila $p$-value $\leq 0,05$ berarti ada hubungan yang bermakna secara statistik dan sebaliknya apabila $p$-value $>0,05$ maka Ho diterima, berarti tidak ada hubungan bermakna secara statistik.

\section{HASIL DAN PEMBAHASAN}

\section{Analisis Univariat}

Tabel 1.Distribusi frekuensi berdasarkan kejadian stunting pada balita, umur ibu, tingkat pendidikan ibu, tinggi badan ibu, riwayat berat badan lahir, ASI eksklusif, kelengkapan imunisasi dasar, paritas, pendapatan keluarga dan riwayat Kekurangan Energi Kronis (KEK) kehamilan.

\begin{tabular}{clcc}
\hline No. & \multicolumn{1}{c}{ Variabel } & Frekuensi & Persentase \\
\hline 1. & Kejadian Stunting Balita & & \\
& Stunting & 92 & 50 \\
& Tidak Stunting & 92 & 50 \\
\hline 2. & Umur Ibu & 55 & \\
& Risiko Tinggi & 129 & 29,9 \\
& Risiko Rendah & & 70,1 \\
\hline 3. & Tingkat Pendidikan Ibu & 110 & 59,8 \\
& Rendah & 74 & 40,2 \\
Tinggi & & \\
\hline 4. & Tinggi Badan Ibu & 58 & 31,5 \\
& Pendek & 126 & 68,5 \\
\hline
\end{tabular}




\begin{tabular}{llcc}
\hline 5. & Riwayat Berat Badan Lahir & & \\
& BBLR & 25 & 13,6 \\
& Normal & 159 & 86,4 \\
\hline 6. & ASI Eksklusif & & \\
& Tidak ASI Eksklusif & 54 & 29,3 \\
& ASI Eksklusif & 130 & 70,7 \\
\hline 7. & Kelengkapan Imunisasi Dasar & & \\
& Tidak Lengkap & 52 & 28,3 \\
& Lengkap & 132 & 71,7 \\
\hline 8. & Paritas & & \\
& >2 Anak & 84 & 45,7 \\
& $\leq 2$ Anak & 100 & 54,3 \\
\hline 9. & Pendapatan Keluarga & & \\
& Rendah & 101 & 54,9 \\
& Tinggi & 83 & 45,1 \\
\hline 10. & Riwayat KEK Kehamilan & & 15,8 \\
& Kekurangan Energi Kronis & 29 & 84,2 \\
\hline & Tidak Kekurangan Energi Kronis & 155 & 100 \\
\hline & Jumlah & 92 & \\
\hline
\end{tabular}

\section{Analisis Bivariat}

Tabel 2. Hubungan umur ibu, tingkat pendidikan ibu, tinggi badan ibu, riwayat berat badan lahir, ASI eksklusif, kelengkapan imunisasi dasar, paritas, pendapatan keluarga, riwayat Kekurangan Energi Kronis (KEK) kehamilan dengan kejadian stunting pada balita

\begin{tabular}{|c|c|c|c|c|c|c|}
\hline \multirow{3}{*}{ Variabel } & \multicolumn{4}{|c|}{$\begin{array}{c}\text { Kejadian Stunting Pada } \\
\text { Balita }\end{array}$} & \multirow[t]{3}{*}{ p-value } & \multirow[t]{3}{*}{ OR } \\
\hline & \multicolumn{2}{|c|}{ Stunting } & \multicolumn{2}{|c|}{$\begin{array}{c}\text { Tidak } \\
\text { Stunting }\end{array}$} & & \\
\hline & $\mathrm{n}$ & $\%$ & $\mathrm{n}$ & $\%$ & & \\
\hline \multicolumn{7}{|l|}{ Umur Ibu } \\
\hline Risiko Tinggi & 24 & 26,1 & 31 & 33,7 & 0,334 & 0,694 \\
\hline Risiko Rendah & 68 & 73,9 & 61 & 66,3 & & \\
\hline \multicolumn{7}{|c|}{ Tingkat Pendidikan Ibu } \\
\hline Rendah & 64 & 69,6 & 46 & 50 & 0,011 & 2,286 \\
\hline Tinggi & 28 & 30,4 & 46 & 50 & & \\
\hline \multicolumn{7}{|l|}{ Tinggi Badan Ibu } \\
\hline Pendek & 31 & 33,7 & 27 & 29,3 & 0,634 & 1,223 \\
\hline Tinggi & 61 & 66,3 & 65 & 70,7 & & \\
\hline \multicolumn{7}{|c|}{ Riwayat Berat Badan Lahir } \\
\hline BBLR & 12 & 13 & 13 & 14,1 & 1,000 & 0,912 \\
\hline Normal & 80 & 87 & 79 & 85,9 & & \\
\hline \multicolumn{7}{|l|}{ ASI Eksklusif } \\
\hline Tidak ASI Eksklusif & 26 & 28,3 & 28 & 30,4 & 0,871 & 0,900 \\
\hline ASI Eksklusif & 66 & 71,7 & 64 & 69,6 & & \\
\hline
\end{tabular}




\begin{tabular}{lcccccc}
\hline $\begin{array}{l}\text { Kelengkapan Imunisasi Dasar } \\
\text { Tidak Lengkap }\end{array}$ & 32 & 34,8 & 20 & 21,7 & 0,072 & 1,920 \\
Lengkap & 60 & 65,2 & 72 & 78,3 & & \\
\hline Paritas & & & & & & \\
$>2$ Anak & 40 & 43,5 & 44 & 47,8 & 0,657 & 0,839 \\
$\leq 2$ Anak & 52 & 56,5 & 48 & 52,2 & & \\
\hline Pendapatan Keluarga & 56 & 60,9 & 45 & 48,9 & 0,138 & 1,625 \\
$\begin{array}{l}\text { Rendah } \\
\text { Tinggi }\end{array}$ & 36 & 39,1 & 47 & 51,1 & & \\
\hline Riwayat KEK Kehamilan & & & & & & \\
KEK & 16 & 17,4 & 13 & 14,1 & 0,686 & 1,279 \\
Tidak KEK & 76 & 82,6 & 79 & 85,9 & & \\
\hline
\end{tabular}

Analisis Multivariat

Tabel 3.Analisis multivariat regresi logistik berganda antara variabel independen dengan kejadian stunting pada balita dengan metode enter

\begin{tabular}{cccc}
\hline Variabel & $\begin{array}{c}p- \\
\text { value }\end{array}$ & OR & $95 \%$ CI \\
\hline Tingkat & 0,031 & 2,072 & $\begin{array}{c}1,068- \\
\text { Pendidikan Ibu }\end{array}$ \\
\hline
\end{tabular}

Pemodelan yang terakhir ini diketahui bahwa variabel yang dominan dapat dilihat dari OR terbesar dan bermakna, semakin besar nilai OR berarti semakin besar pengaruhnya terhadap variabel dependen yang dianalisis. Berdasarkan hasil pemodelan terakhir didapatkan bahwa variabel tingkat pendidikan ibu merupakan variabel dominan dengan OR 2,072. OR 2,072 artinya tingkat pendidikan ibu yang rendah memiliki peluang risiko terjadinya stunting pada balita sebesar 2,072 kali lebih besar dibandingkan tingkat pendidikan ibu yang tinggi.

\section{Umur Ibu dengan kejadian stunting pada balita di wilayah kerja Puskesmas Pekauman Kota Banjarmasin}

Berdasarkan hasil penelitian yang dilakukan di wilayah kerja Puskesmas Pekauman Kota Banjarmasin tahun 2019 diperoleh bahwa umur ibu risiko tinggi dan stunting pada balita sebesar 26,1\% sedangkan umur ibu risiko rendah dan stunting pada balita sebesar 73,9\%. Berdasarkan uji statistik hubungan antara umur ibu dengan stunting pada balita diperoleh $p$-value $=0,334$ dengan demikian $p$-value lebih besar dari nilai $\alpha(0,05)$, hal ini berarti secara statistik tidak ada hubungan bermakna antara umur ibu dengan stunting pada balita.

Sejalan dengan penelitian yang dilakukan Rochmah (2017) diketahui bahwa proporsi usia ibu resiko tinggi memiliki anak stunting sebanyak $60 \%$ dan usia ibu resiko rendah memiliki anak stunting sebanyak $33,8 \%$. Jumlah anak stunting lebih didominasi oleh ibu dengan kategori usia resiko rendah. Pada penelitian ini didapatkan $p$-value dari uji statistik 0,081 ( $\mathrm{p}>0,05)$ dan diartikan bahwa usia ibu tidak memiliki hubungan dengan stunting pada balita usia 24-59 bulan di wilayah kerja Puskesmas Wonosari I.

Usia ibu terlalu muda atau terlalu tua pada waktu hamil dapat menyebabkan stunting pada anak terutama karena pengaruh faktor psikologis. Ibu yang terlalu muda biasanya belum siap dengan kehamilannya dan tidak tahu bagaimana menjaga dan merawat kehamilan. Sedangkan ibu yang usianya terlalu tua biasanya staminanya sudah menurun dan semangat dalam merawat kehamilannya sudah berkurang. Faktor psikologis sangat mudah dipengaruhi oleh faktor lain (Candra, 2013). 
Hasil penelitian yang saya lakukan membuktikan bahwa tidak adanya hubungan antara umur ibu dengan stunting pada balita, kemungkinan dikarenakan umur ibu yang mempunyai risiko tinggi $(<19$ tahun dan $>$ 35 tahun) hanya dapat memberikan kontribusi untuk terjadinya stunting pada balita sebesar $26,1 \%$, sedangkan umur ibu yang mempunyai risiko rendah $(\geq 19$ tahun dan $\leq 35$ tahun) memberikan kontribusi untuk terjadinya stunting pada balita sebesar $73,9 \%$. Umur ibu yang mempunyai risiko rendah ( $\geq 19$ tahun dan $\leq 35$ tahun) harus tetap menjaga kesehatan bayinya selama 1000 Hari Pertama Kehidupan (HPK), serta aktif ke fasilitas kesehatan dalam rangka memantau pertumbuhan dan perkembangan balitanya. fenomena ini membuktikan bahwa kemungkinan variabel umur ibu bukan faktor mendasar dalam menyebabkan stunting pada balita.

Tingkat Pendidikan Ibu dengan kejadian stunting pada balita di wilayah kerja Puskesmas Pekauman Kota Banjarmasin

Berdasarkan hasil penelitian yang dilakukan di wilayah kerja Puskesmas Pekauman Kota Banjarmasin tahun 2019 diperoleh bahwa tingkat pendidikan ibu yang rendah dan stunting pada balita sebesar 69,6\% sedangkan tingkat pendidikan ibu yang tinggi dan stunting pada balita sebesar $30,4 \%$. Berdasarkan uji statistik hubungan antara tingkat pendidikan ibu dengan stunting pada balita diperoleh p-value $=$ 0,011 dengan demikian $p$-value lebih kecil dari nilai $\alpha(0,05)$, hal ini berarti secara statistik terdapat hubungan bermakna antara tingkat pendidikan ibu dengan stunting pada balita.

Berdasarkan hasil penelitian yang dilakukan oleh Setiawan dkk (2018) menyatakan bahwa ada hubungan yang bermakna antara tingkat pendidikan ibu dengan kejadian stunting. Berdasarkan analisis multivariat, faktor pendidikan ibu merupakan faktor yang memiliki hubungan paling dominan dengan kejadian stunting pada anak.

Sejalan dengan

penelitian Mustikaningrum dkk (2016) menyatakan bahwa proporsi responden yang mempunyai tingkat pendidikan $\leq$ SLTP dan stunting sebesar $65,9 \%$ sedangkan proporsi responden yang mempunyai tingkat pendidikan $\geq$ SLTA dan stunting sebesar $34,1 \%$, dengan $p$-value 0,05 , berarti adanya hubungan antara tingkat pendidikan ibu dengan kejadian stunting pada bayi usia 6 bulan di kota Semarang. Nilai OR didapatkan sebesar 1,81 (0,993,29 ) yang artinya tingkatan pendidikan ibu $\leq$ SLTP mempunyai peluang risiko $1,81 \mathrm{kali}$ lebih besar terjadinya stunting pada bayi usia 6 bulan di kota Semarang dibandingkan responden yang mempunyai tingkat pendidikan $\geq$ SLTA.

Sejalan dengan pendapat Soetjiningsih (1998) dalam Kusumaningrum (2003) menyatakan bahwa pendidikan orang tua merupakan salah satu faktor penting dalam tumbuh kembang anak, karena pendidikan yang baik, maka orang tua dapat menerima segala informasi dari luar, terutama tentang cara pengasuhan anak yang baik.

Berdasarkan hasil penelitian yang saya lakukan membuktikan bahwa variabel pendidikan ibu berperan penting terhadap terjadinya stunting pada balita, karena pendidikan gizi kepada masayarakat, khususnya pendidikan gizi kepada ibu balita merupakan salah satu intervensi gizi sensitif serta pendidikan berkaitan dengan pola pikir seseorang dalam melihat suatu masalah terhadap kesehatan, maka edukasi secara komprehensif dan intensif kepada ibu balita mengenai stunting pada balita akan berperan penting terhadap pola asuh selama 1000 Hari Pertama Kehidupan (HPK), yang pada akhirnya mempunyai potensi terhadap penurunan stunting pada balita.

\section{Tinggi Badan Ibu dengan kejadian stunting pada balita di wilayah kerja Puskesmas Pekauman Kota Banjarmasin}


Berdasarkan hasil penelitian yang dilakukan di wilayah kerja Puskesmas Pekauman Kota Banjarmasin tahun 2019 diperoleh bahwa ibu yang mempunyai tinggi badan pendek dan stunting pada balita sebesar $33,7 \%$ sedangkan ibu yang mempunyai tinggi badan tinggi dan stunting pada balita sebesar $66,3 \%$. Berdasarkan uji statistik hubungan antara tinggi badan ibu dengan stunting pada balita diperoleh $p$ value $=0,634$ dengan demikian $p$-value lebih besar dari nilai $\alpha(0,05)$, hal ini berarti secara statistik tidak ada hubungan bermakna antara tinggi badan ibu dengan stunting pada balita.

Hasil penelitian saya berbeda dengan hasil penelitian yang dilakukan oleh Nasrul dkk (2015) menyatakan bahwa tinggi badan $\mathrm{ibu}<150 \mathrm{~cm}$ dan stunting sebanyak 71 $(59,2 \%)$ sedangkan tinggi badan ibu $\geq 150$ $\mathrm{cm}$ dan stunting sebanyak $95 \quad(41,3 \%)$ dengan $p$-value 0,001 , yang berarti terdapat hubungan yang bermakna antara tinggi badan ibu dengan stunting usia 6-23 bulan di Kecamatan Bontoramba Kabupaten Jeneponto dengan OR (95\% CI) sebesar $1,970(1,218-3,187)$ yang berarti ibu yang mempunyai tinggi badan $<150 \mathrm{~cm}$ mempunyai peluang risiko 1,970 kali lebih besar dari ibu dengan tinggi badan $\geq 150 \mathrm{~cm}$.

Hasil penelitian saya membuktikan bahwa variabel tinggi badan ibu tidak sepenuhnya memberikan kontribusi bagi terjadinya stunting pada balita keturunannya, karena dengan mengatur pola asuh yang baik dengan memberikan asupan gizi balita secara seimbang, maka masa pertumbuhan dan perkembangan seluruh organ tubuh termasuk pertumbuhan tulang akan menjadi baik dan aktif dalam melakukan kunjungan ke fasilitas kesehatan untuk memantau pertumbuhan dan perkembangan balita.

Riwayat berat badan lahir dengan kejadian stunting pada balita di wilayah kerja Puskesmas Pekauman Kota Banjarmasin

Berdasarkan hasil penelitian yang dilakukan di wilayah kerja Puskesmas
Pekauman Kota Banjarmasin tahun 2019 diperoleh bahwa riwayat Berat Badan Lahir Rendah (BBLR) dan stunting pada balita sebesar 13\% sedangkan riwayat Berat Badan Lahir Normal (BBLN) dan stunting pada balita sebesar $87 \%$. Berdasarkan uji statistik hubungan antara riwayat berat badan lahir dengan stunting pada balita diperoleh $p$ value $=1,000$ dengan demikian $p$-value lebih besar dari nilai $\alpha(0,05)$, hal ini berarti secara statistik tidak ada hubungan bermakna antara riwayat berat badan lahir dengan stunting pada balita.

Berat badan lahir adalah berat badan bayi ketika lahir atau paling lambat sampai bayi berumur 1 hari dilihat dari KMS (Kartu Menuju Sehat) dimana bila berat badan lahir kurang dari 2500 gram berarti berat badan lahir rendah dan bila lebih dari atau sama dengan 2500 gram berarti normal. Berat badan lahir rendah banyak dihubungkan dengan tinggi badan yang kurang atau stunting pada balita (Kusharisupeni, 2002).

Berat Badan Lahir Rendah (BBLR), yaitu berat bayi lahir kurang dari 2.500 gram, akan membawa risiko kematian, gangguan pertumbuhan dan perkembangan anak, termasuk dapat berisiko menjadi pendek jika tidak tertangani dengan baik (Pusdatin Kemenkes RI, 2016). Anak dengan riwayat BBLR merupakan salah satu faktor yang potensial memengaruhi pertumbuhan anak. Terdapat hubungan yang signifikan antara riwayat status BBLR dengan stunting pada anak baduta (Rahayu, dkk, 2015).

Penelitian Azriful dkk (2018) menyatakan bahwa proporsi responden BBLR dan stunting sebesar $89,7 \%$ sedangkan proporsi responden tidak BBLR dan stunting sebesar 68,2\% dengan p-value $(0,033)$ yang artinya adanya hubungan yang bermakna antara Berat Badan Lahir Rendah (BBLR) dengan kejadian stunting pada balita usia 24-59 bulan di Kelurahan Rangas Kecamatan Banggae Kabupaten Majene.

Berdasarkan hasil penelitian yang saya lakukan di wilayah kerja Puskesmas Pekauman Kota Banjarmasin tahun 2019 
membuktikan bahwa sebagian besar balita dengan riwayat Berat Badan Lahir Rendah (BBLR) memberikan kontribusi untuk stunting sebesar $13 \%$, berarti BBLR bukan sebagai faktor risiko yang mendasar untuk terjadinya stunting pada balita di wilayah kerja Puskesmas Pekauman Kota Banjarmasin tahun 2019, karena apabila balita ada riwayat Berat Badan Lahir Rendah (BBLR), maka dapat diperbaiki dengan menjaga pola asuh sampai 2 tahun dan memberikan asupan gizi seimbang pada balita, sedangkan Berat Badan Lahir Normal (BBLN) sebagian besar mengalami stunting pada balita yaitu sebesar $87 \%$, hal ini terjadi kemungkinan ada variabel yang mengakibatkan fenomena ini terjadi, yaitu menurut asumsi saya menyatakan bahwa ketahanan dan ketersediaan pangan setiap keluarga berpotensi mempunyai hubungan terhadap kualitas makanan yang di konsumsi, dimana kualitas konsumsi makanan, erat hubunganya terhadap pendapatan keluarga, kemudian pendapatan keluarga berpotensi terhadap daya beli masyarakat untuk dapat memenuhi kebutuhan asupan gizi yang seimbang pada balita.

\section{ASI eksklusif dengan kejadian stunting pada balita di wilayah kerja Puskesmas Pekauman Kota Banjarmasin}

Berdasarkan hasil penelitian yang dilakukan di wilayah kerja Puskesmas Pekauman Kota Banjarmasin tahun 2019 diperoleh bahwa balita yang tidak ASI eksklusif dan stunting pada balita sebesar $28,3 \%$ sedangkan balita yang ASI eksklusif dan stunting pada balita sebesar 71,7\%. Berdasarkan uji statistik hubungan antara ASI eksklusif dengan stunting pada balita diperoleh $p$-value $=0,871$ dengan demikian $p$-value lebih besar dari nilai $\alpha(0,05)$, hal ini berarti secara statistik tidak ada hubungan bermakna antara ASI eksklusif dengan stunting pada balita.

ASI sudah cukup untuk menjaga pertumbuhan bayi sampai usia 6 bulan. Tidak ada makanan lain yang dibutuhkan selama masa ini. ASI bersifat steril, berbeda dengan susu lain seperti susu formula atau cairan lain yang disiapkan dengan air atau bahan lainnya yang dapat terkontaminasi dalam botol yang kotor. Pemberian ASI saja, tanpa cairan atau makanan lain dan tanpa menggunakan botol, menghindarkan anak dari bahaya bakteri dan organisme lain yang akan menyebabkan diare (Kemenkes RI, 2011).

World Health Organization (WHO) menyebutkan bahwa ASI eksklusif adalah pemberian hanya ASI saja tanpa cairan atau makanan padat apapun kecuali vitamin, mineral atau obat dalam betuk tetes atau sirup sampai bayi usia enam bulan. Pemberian ASI eksklusif sejak bayi dilahirkan sangat baik dilakukan karena bayi akan memperoleh kolostrum, yang berupa air susu ibu berwarna kekuningan yang keluar di hari pertama sampai hari ke tiga saat ibu mulai menyusui. Kolostrum sangat baik karena berprotein tinggi, kaya akan zat anti infeksi, dan dapat meningkatkan daya tahan tubuh bayi (KPPPA, 2018).

Rendahnya pemberian ASI eksklusif menjadi salah satu pemicu terjadinya stunting pada anak balita yang disebabkan oleh kejadian masa lalu dan akan berdampak terhadap masa depan anak balita, sebaliknya pemberian ASI yang baik oleh ibu akan membantu menjaga keseimbangan gizi anak sehingga tercapai pertumbuhan anak yang normal (Aridiyah dkk., 2015).

Penelitian dilakukan oleh Azriful dkk (2018) menyatakan bahwa proporsi responden yang mendapatkan ASI eksklusif dan stunting sebesar 89,2\% sedangkan proporsi responden yang tidak mendapatkan ASI eksklusif dan stunting sebesar $57 \%$ dengan $p$-value 0,000 yang artinya adanya hubungan yang bermakna antara ASI eksklusif dengan kejadian stunting pada balita usia 24-59 bulan di Kelurahan Rangas Kecamatan Banggae Kabupaten Majene.

Hasil penelitian saya menyatakan bahwa secara statistik tidak ada hubungan bermakna antara ASI eksklusif dengan 
stunting pada balita, hal ini menyatakan bahwa untuk mencegah stunting pada balita, tidak cukup hanya melakukan pemberian ASI eksklusif saja, akan tetapi perlu pola asuh yang dilakukan secara intensif mulai dari lahir sampai 2 tahun (1000 HPK), dengan asupan gizi yang seimbang serta aktif melakukan kunjungan ke fasilitas kesehatan minimal 8 kali kunjungan selama 1 tahun terakhir dalam rangka memantau pertumbuhan dan perkembangan balita.

Kelengkapan imunisasi dasar dengan kejadian stunting pada balita di wilayah kerja Puskesmas Pekauman Kota Banjarmasin

Berdasarkan hasil penelitian yang dilakukan di wilayah kerja Puskesmas Pekauman Kota Banjarmasin tahun 2019 diperoleh bahwa balita yang tidak lengkap imunisasi dasar dan stunting pada balita sebesar $34,8 \%$ sedangkan balita yang lengkap imunisasi dasar dan stunting pada balita sebesar 65,2\%. Berdasarkan uji statistik hubungan antara kelengkapan imunisasi dasar dengan stunting pada balita diperoleh $p$-value $=0,072$ dengan demikian $p$-value lebih besar dari nilai $\alpha(0,05)$, hal ini berarti secara statistik tidak ada hubungan bermakna antara kelengkapan imunisasi dasar dengan kejadian stunting pada balita.

Pemberian imunisasi pada anak memiliki tujuan penting yaitu untuk mengurangi risiko mordibitas (kesakitan) dan mortalitas (kematian) anak akibat Penyakit yang Dapat Dicegah Dengan Imunisasi (PD3I). Penyakit-penyakit tersebut antara lain: TBC, difteri, tetanus, pertussis, polio, campak, hepatitis B, dan sebagainya. Status imunisasi pada anak adalah salah satu indikator kontak dengan pelayanan kesehatan. Karena diharapkan bahwa kontak dengan pelayanan kesehatan akan membantu memperbaiki masalah gizi baru jadi status imunisasi diharapkan akan memberikan efek positif terhadap status gizi jangka panjang (Yimer, 2000).

Hasil penelitian Picauly dan Toy (2013) dengan analisis regresi logistik menunjukkan bahwa anak yang tidak memiliki riwayat imunisasi memiliki peluang mengalami stunting lebih besar dibandingkan anak yang memiliki riwayat imunisasi. Hal ini berarti bahwa jika anak tidak memiliki riwayat imunisasi maka akan diikuti dengan peningkatan kejadian stunting 1.983 kali.

Hasil penelitian saya membuktikan bahwa secara statistik tidak ada hubungan bermakna antara kelengkapan imunisasi dasar dengan stunting pada balita, hal ini menyatakan bahwa untuk mencegah stunting pada balita, tidak cukup hanya melakukan imunisasi dasar secara lengkap saja, akan tetapi perlu pola asuh yang dilakukan secara intensif mulai dari lahir sampai 1000 Hari Pertama Kehidupan (HPK), salah satunya adalah dengan memberikan asupan gizi yang seimbang, karena 1000 HPK merupakan masa perkembangan dan pertumbuhan bayi dan balita.

Paritas dengan kejadian stunting pada balita di wilayah kerja Puskesmas Pekauman Kota Banjarmasin

Berdasarkan hasil penelitian yang dilakukan di wilayah kerja Puskesmas Pekauman Kota Banjarmasin tahun 2019 diperoleh bahwa ibu yang mempunyai lebih dari 2 Anak dan stunting pada balita sebesar $43,5 \%$ sedangkan ibu yang mempunyai kurang dari atau sama dengan 2 anak dan stunting pada balita sebesar 56,5\%. Berdasarkan uji statistik hubungan antara paritas dengan stunting pada balita diperoleh $p$-value $=0,657$ dengan demikian $p$-value lebih besar dari nilai $\alpha(0,05)$, hal ini berarti secara statistik tidak ada hubungan bermakna antara paritas dengan stunting pada balita.

Berdasarkan hasil penelitian yang dilakukan oleh Palino dkk (2017) diketahui bahwa dari 65 pasangan balita yang telah dimatchingkan umurnya,pada kelompok kasus, balita yang memiliki ibu dengan paritas banyak relatif lebih banyak yaitu $40,0 \%$, sedangkan pada kelompok kontrol hanya sebesar $12,3 \%$. Sebaliknya pada kelompok kasus, balita yang memiliki ibu 
dengan paritas sedikit relatif lebih sedikit yaitu hanya $12,3 \%$, sedangkan pada kelompok kontrol sebesar 40,0\%. Dengan demikian secara deskriptif dapat dijelaskan bahwa pada balita stunting lebih banyak yang memiliki ibu dengan paritas banyak dibandingkan ibu dengan paritas sedikit. Sedangkan pada balita yang tidak stunting lebih banyak memiliki ibu dengan paritas sedikit dibandingkan ibu dengan paritas banyak. Dengan demikian dapat dikatakan bahwa pada balita yang stunting cenderung memiliki ibu dengan pasitas banyak, sedangkan pada balita yang tidak stunting cenderung memiliki ibu dengan paritas banyak. Hasil analisis besar pengaruh paritas terhadap kejadian stunting, setelah dimatching umur ini, diperoleh OR sebesar 3,25 . Artinya balita yang memiliki ibu dengan paritas banyak mempunyai risiko mengalami stunting 3,25 kali lebih besar dibandingkan dengan balita yang memiliki ibu dengan paritas sedikit, karena rentang nilai pada tingkat kepercayaan $(\mathrm{CI})=95 \%$ dengan lower limit (batas bawah) $=1,428$ dan upper limit (batas atas) $=8,305$ tidak mencakup nilai satu, maka besar risiko tersebut bermakna. Dengan demikian, setelah dimatching umur, paritas merupakan determinan kejadian stunting pada balita usia 12-59 bulan di wilayah kerja puskesmas Puuwatu kota kendari tahun 2016. Hasil analisis antara paritas terhadap kejadian stunting menggunakan uji McNemar menunjukkan bahwa nilai $\rho(0,0029)<$ a $(0,05)$ sehingga disimpulkan ada hubungan yang signifikan antara paritas terhadap kejadian stunting pada balita usia 12-59 bulan di wilayah kerja Puskesmas Puuwatu tahun 2016.

Ibu dengan paritas banyak cenderung akan memiliki anak yang mengalami stunting. Hal ini disebabkan oleh keluarga yang memiliki banyak anak terutama dengan kondisi ekonomi kurang tidak akan dapat memberikan perhatian dan makanan yang cukup pada seluruh anak-anaknya. Anak yang sedang dalam masa pertumbuhan terutama masa pertumbuhan cepat seperti pada usia 1-2 tahun sangat membutuhkan perhatian dan stimulasi untuk perkembangan otaknya disamping membutuhkan zat gizi yang lengkap untuk pertumbuhan fisiknya. Gangguan pertumbuhan dan perkembangan cenderung akan dialami oleh anak yang dilahirkan belakangan, karena beban yang ditangggung orangtua semakin besar dengan semakin banyaknya jumlah anak yang dimiliki (Palino dkk., 2017).

Menurut pendapat saya, dilihat dari hasil penelitian yang saya lakukan dengan dibandingkan dengan hasil penelitian yang lain, ini menyatakan bahwa stunting pada balita tidak semata mata disebabkan oleh paritas atau jumlah anak, melainkan ada faktor yang kemungkinan lebih besar berpengaruh terhadap terjadinya stunting pada balita di wilayah kerja Puskesmas Pekauman Kota Banjarmasin.

Pendapatan keluarga dengan kejadian stunting pada balita di wilayah kerja Puskesmas Pekauman Kota Banjarmasin

Berdasarkan hasil penelitian yang dilakukan di wilayah kerja Puskesmas Pekauman Kota Banjarmasin tahun 2019 diperoleh bahwa pendapatan keluarga yang rendah dan stunting pada balita sebesar $60,9 \%$ sedangkan pendapatan keluarga yang tinggi dan stunting pada balita sebesar $39,1 \%$. Berdasarkan uji statistik hubungan antara pendapatan keluarga dengan stunting pada balita diperoleh $p$-value $=0,138$ dengan demikian $p$-value lebih besar dari nilai $\alpha(0,05)$, hal ini berarti secara statistik tidak ada hubungan bermakna antara pendapatan keluarga dengan kejadian stunting pada balita.

Orang tua dengan pendapatan keluarga yang memadai akan memiliki kemampuan untuk menyediakan semua kebutuhan primer dan sekunder anak. Keluarga dengan status ekonomi yang baik juga memiliki akses pelayanan kesehatan yang lebih baik. Anak pada keluarga dengan status ekonomi rendah cenderung mengkonsumsi makanan dalam segi kuantitas, kualitas, serta variasi yang 
kurang. Status ekonomi yang tinggi membuat seseorang memilih dan membeli makanan yang bergizi dan bervariasi (Pipes, 1985 dalam Setiawan dkk., 2018).

Berdasarkan data Joint Child Malnutrition Estimates tahun 2018, negara dengan pendapatan menengah ke atas mampu menurunkan angka stunting hingga $64 \%$, sedangkan pada Negara menengah ke bawah hanya menurunkan sekitar $24 \%$ dari tahun 2000 hingga 2017. Pada Negara dengan pendapatan rendah justru mengalami peningkatan pada tahun 2017 (Infodatin Kemenkes RI, 2018).

Penelitian Mustikaningrum dkk (2016) menyatakan bahwa proporsi responden yang mempunyai pendapatan rendah dan stunting sebesar 76,9\% sedangkan proporsi responden yang mempunyai pendapatan cukup dan stunting sebesar $23,1 \%$, dengan p-value 0,001 , berarti adanya hubungan antara tingkat ekonomi keluarga dengan kejadian stunting pada bayi usia 6 bulan di kota Semarang. Nilai OR didapatkan sebesar 6,14 (3,20-11,77) yang artinya responden yang mempunyai pendapatan rendah berpeluang risiko 6,14 kali lebih besar terjadinya stunting pada bayi usia 6 bulan di kota Semarang dibandingkan responden yang mempunyai pendapatan cukup.

Berdasarkan hasil penelitian yang saya lakukan di wilayah kerja Puskesmas Pekauman Kota Banjarmasin tahun 2019 diperoleh bahwa pendapatan keluarga yang rendah dan stunting pada balita sebesar $60,9 \%$, artinya pendapatan keluarga yang rendah mampu memberikan kontribusi untuk terjadinya stunting pada balita cukup besar, walaupun secara statistik tidak terdapat hubungan yang bermakna antara pendapatan keluarga dengan kejadian stunting pada balita, menurut pendapata saya adanya kemungkinan ini terjadi, dikarenakan adanya pola pikir yang berbeda mengenai pentingnya asupan gizi seimbang pada balita, yaitu persepsi ibu balita mengenai pentingnya asupan gizi seimbang pada balita, dimana persepsi ibu balita terbentuk dari tingkat pendidikan seorang ibu balita.

Riwayat Kekurangan Energi Kronis (KEK) pada saat kehamilan dengan kejadian stunting pada balita di wilayah kerja Puskesmas Pekauman Kota Banjarmasin

Berdasarkan hasil penelitian yang dilakukan di wilayah kerja Puskesmas Pekauman Kota Banjarmasin tahun 2019 diperoleh bahwa riwayat Kekurangan Energi Kronis (KEK) pada saat kehamilan dan stunting pada balita sebesar 17,4\% sedangkan tidak ada riwayat Kekurangan Energi Kronis (KEK) pada saat kehamilan dan stunting pada balita sebesar $82,6 \%$. Berdasarkan uji statistik hubungan antara riwayat Kekurangan Energi Kronis (KEK) pada saat kehamilan dengan kejadian stunting pada balita diperoleh p-value $=$ 0,686 dengan demikian $p$-value lebih besar dari nilai $\alpha(0,05)$, hal ini berarti secara statistik tidak ada hubungan bermakna antara riwayat Kekurangan Energi Kronis (KEK) pada saat kehamilan dengan kejadian stunting pada balita.

Berdasarkan hasil penelitian yang dilakukan oleh Sukmawati dkk (2018) menunjukkan bahwa status gizi ibu yang KEK dengan status gizi anak normal berdasarkan TB/U sebanyak $6.3 \%$ dan status gizi ibu yang KEK dengan status gizi anak berdasarkan TB/U (stunting) sebanyak $22.1 \%$ sedangkan status gizi ibu yang normal berdasarkan LILA dengan status gizi anak berdasarkan $\mathrm{TB} / \mathrm{U}$ (normal) sebanyak $44.2 \%$ dan status gizi ibu yang normal berdasarkan LILA dengan status gizi anak berdasarkan $\mathrm{TB} / \mathrm{U} \quad$ (stunting) sebanyak $27.4 \%$. Berdasarkan uji statistik diperoleh nilai $p=$ $(0,01)$ yang lebih kecil dari nilai $\alpha(0.05)$ yang berarti ada hubungan antara status gizi ibu berdasarkan LILA dengan kejadian stunting.

Pertumbuhan dan perkembangan bayi dipengaruhi kondisi sejak dalam kandungan ibu. Ibu hamil KEK merupakan penyebab 25-30 \% Intrauterine Growth Retardation 
(IUGR) pada janin dan keadaan ini akan diturunkan dari satu generasi ke generasi dan pertumbuhan anak tidak maksimal di tahuntahun berikutnya (PERSAGI, 2009 dalam Sukmawati dkk., 2018).

Berdasarkan hasil penelitian yang saya lakukan diperoleh bahwa riwayat Kekurangan Energi Kronis (KEK) pada saat kehamilan dan stunting pada balita sebesar $17,4 \%$ sedangkan tidak ada riwayat Kekurangan Energi Kronis (KEK) pada saat kehamilan dan stunting pada balita sebesar 82,6\%. Berarti riwayat Kekurangan Energi Kronis (KEK) dapat diperbaiki selama kehamilan, dengan cara intervasi kepada ibu hamil seperti asupan gizi seimbang pada ibu hamil serta perlu peningkatan edukasi kepada ibu hamil agar dapat memahami asupan gizi seimbang selama hamil dan di fasilitasi untuk mendapatkan PMT selama hamil dalam rangka memperbaiki status gizi ibu hamil.

\section{SIMPULAN}

Berdasarkan hasil penelitian di wilayah kerja Puskesmas Pekauman Tahun 2019 menyatakan bahwa sebagian besar umur ibu yang mempunyai risiko rendah sebesar 70,1\%. Sebagian besar tingkat pendidikan ibu rendah sebesar 59,8\%. Sebagian besar ibu yang mempunyai tinggi badan sebesar $68,5 \%$. Sebagian besar riwayat berat badan lahir normal sebesar 86,4. Sebagian besar balita ASI eksklusif sebesar 70,7\%. Sebagian besar balita melakukan imunisasi dasar lengkap sebesar $71,7 \%$. Sebagian besar ibu yang mempunyai kurang dari atau sama dengan dua anak sebesar 54,3\%. Sebagian besar pendapatan keluarga rendah sebesar 54,9\%. Sebagian besar ibu tidak memiliki Kekurangan Energi Kronis (KEK) pada saat kehamilan sebesar $84,2 \%$. Secara statistik terdapat hubungan yang bermakna antara tingkat pendidikan ibu dengan kejadian stunting pada balita di wilayah kerja Puskesmas Pekauman Kota Banjarmasin dengan $p$-value $(0,011)<\alpha(0,05)$. Variabel dominan dengan kejadian stunting pada balita adalah tingkat pendidikan ibu dengan nilai OR (2,072), artinya tingkat pendidikan ibu yang rendah mempunyai peluang risiko terjadinya stunting pada balita 2,072 kali lebih besar dibandingkan dengan tingkat pendidikan ibu yang tinggi.

\section{SARAN}

Disarankan perlunya adanya edukasi secara komprehensif dan intensif mengenai pola asuh selama 1.000 Hari Pertama Kehidupan (HPK) sampai berusia balita, agar dapat mengubah pola pikir ibu balita mengenai pentingnya asupan gizi seimbang pada balita terhadap pertumbuhan dan perkembangan balita.

\section{UCAPAN TERIMA KASIH}

Penulis mengucapkan terima kasih kepada Lembaga Penelitian dan Pengabdian pada Masyarakat (LP2M) Universitas Islam Kalimantan Muhammad Arsyad Al Banjari Banjarmasin yang telah memberikan dana penelitian APBU skema PDP dan Kepala Puskesmas Pekauman Kota Banjarmasin yang telah memberikan izin untuk melaksanakan kegiatan penelitian serta petugas kesehatan dan enumerator yang telah membantu dalam kelancaran kegiatan penelitian ini.

\section{DAFTAR PUSTAKA}

Aridiyah FO, Rohmawati N, Ririanty M., 2015. e-Jurnal Pustaka Kesehatan. Faktor-faktor yang mempengaruhi kejadian stunting pada anak balita di wilayah pedesaan dan perkotaan (The Factors Affecting Stunting on Toddlers in Rural and Urban Areas). Vol.3, No. 1. [Online]. https://jurnal.unej.ac.id/index.php/JP K/article/view/2520. [diakses tanggal 16 Mei 2020].

Azriful, Bujawati, Emmi., Habibi, Aeni, Syahratul dan Yusdarif., 2018. AlSihah : Public Health Science Journal. Determinan Kejadian Stunting pada Balita Usia 24-59 Bulan di Kelurahan Rangas Kecamatan Banggae 
Kabupaten Majene. Vol. 10, No. 2, Juli-Desember 2018. [Online]. http://journal.uinalauddin.ac.id/index.php/Al-

Sihah/article/view/6874. [diakses tanggal 16 Mei 2020].

Badan Penelitian dan Pengembangan Kesehatan (Balitbangkes) Kemenkes RI, 2007. Riset Kesehatan Dasar (RISKESDAS 2007). Jakarta : Balitbangkes

Kemenkes.[Online].http://kesga.kemke s.go.id/images/pedoman/Riskesdas $\% 20$ 2007\%20Nasional.pdf [diakses tanggal 14 September 2019].

Badan Penelitian dan Pengembangan Kesehatan (Balitbangkes) Kemenkes RI, 2010. Riset Kesehatan Dasar (RISKESDAS 2010). Jakarta : Balitbangkes

Kemenkes.[Online].http://kesga.kemke s.go.id/images/pedoman/Riskesdas $\% 20$ 2010\%20Nasional.pdf. [diakses tanggal 14 September 2019].

Badan Penelitian dan Pengembangan Kesehatan (Balitbangkes) Kemenkes RI, 2013. Riset Kesehatan Dasar (RISKESDAS 2013). Jakarta : Balitbangkes

Kemenkes.[Online].http://www.depkes .go.id/resources/download/general/Has il\%20Riskesdas\%202013.pdf. [diakses tanggal 14 September 2019].

Badan Penelitian dan Pengembangan Kesehatan (Balitbangkes) Kemenkes RI, 2018. Riset Kesehatan Dasar (RISKESDAS 2018). Jakarta : Balitbangkes Kemenkes.[Online]. http://www.depkes.go.id/resources/do wnload/infoterkini/materi_rakorpop_2018/Hasil\%2 0Riskesdas\%202018.pdf. [diakses tanggal 14 September 2019].

Badan Perencanaan dan Pembangunan Nasional (Bappenas), 2018. Pedoman Pelaksanaan : Intervensi Penurunan Stunting Terintegrasi di Kabupaten/Kota. Edisi November
2018.[Online].http://tnp2k.go.id/filema nager/files/Rakornis\%202018/Pedoma n\%20Pelaksanaan\%20Intervensi\%20P enurunan\%20Stunting\%20Terintegrasi \%20Di\%20Kabupaten\%20Kota.pdf. [diakses tanggal 14 September 2019].

Candra, Aryu., 2013. Journal of Nutrition and Health. Hubungan Underlying Factors Dengan Kejadian Stunting Pada Anak 1-2 Th. Vol. 1, No. 1. [Online].

https://ejournal.undip.ac.id/index.php/a ctanutrica/article/view/4847/0. [diakses tanggal 15 Mei 2020].

Kusharisupeni, 2002. Peran status kelahiran terhadap stunting pada bayi: sebuah studi prospektif. Jurnal Kedokteran Trisakti. Vol. 23 ; p.73-80.

Kusumaningrum, Nugraheni Restu., 2003. Skripsi. Pengaruh Tingkat Pendidikan Ibu, Aktivitas Ekonomi Ibu dan Pendapatan Keluarga Terhadap Status Gizi Balita di Kecamatan Simo, Kabupaten Boyolali. Fakultas Ekonomi, Universitas Sebelas Maret Surakarta.[Online]. https://core.ac.uk/download/pdf/16507 639.pdf. [diakses tanggal 16 Mei 2020].

Kemeterian Kesehatan RI, 2011. Situasi Diare di Indonesia. Jakarta: Kemenkes RI.

Kementerian Pemberdayaan Perempuan dan Perlindungan Anak (KPPPA), 2018. Profil Anak Indonesia 2018. Jakarta :Kementerian Pemberdayaan Perempuan dan Perlindungan Anak (KPPPA). [Online]. https://kemenpppa.go.id/index.php/pag e/read/25/2147/profil-anak-indonesiatahun-2018. [diakses tanggal $17 \mathrm{Mei}$ 2020].

Mustikaningrum, Ardian Candra., Subagio Hertanto W dan Margawati, Ani., 2016. Jurnal Gizi Indonesia (The Indonesian Journal of Nutrition). Determinan Kejadian Stunting pada Bayi Usia 6 Bulan di Kota Semarang. 
Vol. $\quad 4, \quad$ No. $\quad 2$

.[Online].https://ejournal.undip.ac.id/in dex.php/jgi/article/view/16302.

[Diakses tanggal 15 Mei 2020].

Nasrul, Hafid, Fahmi., Thaha, Abdul Razak., Suriah., 2015. Jurnal MKMI. Faktor Risiko Stunting Usia 6-23 Bulan di Kecamatan Bontoramba Kabupaten Jeneponto. Vol. 11, No.3 September 2015.

[Online].

http://journal.unhas.ac.id/index.php/mk mi/article/view/518. [Diakses tanggal 15 Mei 2020].

Palino, Inochi Lara., Majid, Ruslan dan Ainurafiq., 2017. Jurnal Ilmiah Mahasiswa Kesehatan Mahasiswa (JIM Kesmas). Determinan Kejadian Stunting pada Balita Usia 12-59 Bulan di Wilayah Kerja Puskesmas Puuwatu Kota Kendari Tahun 2016. Vol. 2, No. 6 Mei $2017 . \quad$ [Online]. http://ojs.uho.ac.id/index.php/JIMKES MAS/article/view/2870. [Diakses tanggal 15 Mei 2020].

Picauly, Intje dan Toy, Sarci Magdalena., 2013. Jurnal Gizi dan Pangan. Analisis Determinan dan Pengaruh Stunting Terhadap Prestasi Belajar Anak Sekolah di Kupang dan Sumba Timur, NTT. Vol. 8, No. 1. [Online]. ournal.ipb.ac.id/index.php/jgizipangan/ article/view/7254. [diakses tanggal 16 Mei 2020].

Pusat Data dan Informasi (Pusdatin) Kemenkes RI, 2016. Infodatin: Situasi Balita Pendek. Jakarta : Pusdatin Kemenkes 2016. [Online]. https://www.kemkes.go.id/resources/d ownload/pusdatin/infodatin/situasibalita-pendek-2016.pdf. [diakses tanggal 15 mei 2020].

Pusat Data dan Informasi (Pusdatin) Kemenkes RI, 2018. Buletin Jendela Data dan Informasi Kesehatan : Situasi Balita Pendek (Stunting) di Indonesia. Semester I 2018. Jakarta : Pusdatin.

Kemenkes2018.[Online].https://pusdati n.kemkes.go.id/resources/download/pu sdatin/buletin/Buletin-Stunting2018.pdf. [diakses tanggal 14 September 2019].

Rahayu A, Yulidasari F, Putri AO, Rahman F., 2015. Jurnal Kesehatan Masyarakat Nasional. Riwayat berat badan lahir dengan kejadian stunting pada anak usia bawah dua tahun. Vol. 10, No. 2 November.

[Online]. http://journal.fkm.ui.ac.id/index.php/ke smas/article/view/882. [Diakses tanggal 15 Mei 2020].

Rochmah, Amalia Miftakhul., 2017. Naskah Publikasi. Faktor-Faktor yang Berhubungan dengan Stunting pada Balita Usia 24-59 Bulan di Wilayah Kerja Puskesmas Wonosari I. Program Studi Bidan Pendidik Jenjang Diploma IV, Fakultas Ilmu Kesehatan, Universitas "Aisyiyah Yogyakarta. [Online]. http://digilib.unisayogya.ac.id/2535/1/AM ALIA\%20MIFTAKHUL\%20ROCHMAH $\% 201610104405 \% 20$ NASKAH\%20PUBL IKASI.pdf. [diakses tanggal 16 Mei 2020]. Setiawan, Eko.,Machmud, Rizanda dan Masrul., 2018. Faktor-Faktor yang Berhubungan dengan Kejadian Stunting pada Anak Usia 24-59 Bulan di Wilayah Kerja Puskesmas Andalas Kecamatan Padang Timur Kota Padang Tahun 2018. Vol. 7, No. 2. [Online].

http://jurnal.fk.unand.ac.id/index.php/jka/a rticle/view/813. [diakses tanggal $16 \mathrm{Mei}$ 2020].

Sukmawati, Hendrayati, Chaerunnimah, Nurhumaira., 2018. Media Gizi Pangan. Status Gizi Ibu Saat Hamil, Berat Badan Lahir Bayi dengan Stunting pada Balita Usia 06-36 Bulan di Puskesmas Bontoa. Vol. 25, No. 1. [Online].

http://journal.poltekkesmks.ac.id/ojs2/i ndex.php/mediagizi/article/view/55. [Diakses tanggal 15 Mei 2020].

Yimer, G., 2000. Malnutrition among children in shouthern ethiopia: levels and risk factors". Ethiop. J. Health Dev, 14(3): 283-292 